\title{
PERLINDUNGAN HUKUM TERHADAP HAK CIPTA BATIK MOTIF CEPLOK SEGORO AMARTO DI KOTA YOGYAKARTA
}

\section{Dyah Ayu Widyastutiningrum}

Universitas Islam Indonesia

Contact : dyahayuwdys@gmail.com

Diterima : 13 Desember 2018 Direvisi : 30 Desember 2018 Disetujui : 1 Januari 2019 Hak Cipta :@2019

Halaman : 36-51

\section{ABSTRACT}

Ceplok Segoro Amarto motive batik is a batik with contemporary motives that are protected by copyright obtained automatically or by means of a mechanism for recording copyright. Dekranasda of Yogyakarta City as the copyright holder has moral and economic rights to duplicate and distribute Ceplok Segoro Amarto motive batik as stated in Article 9 of the Copyright Law. Even though it has been protected by copyright, in fact there is still a copyright infringement of Ceplok Segoro Amarto motive batik which is done by piracy by other parties without the permission of the copyright holder in an unlawful manner. This study aims to determine the legal protection of the copyright of the Segoro Amarto Ceplok motive batik as stipulated in Undang-Undang Nomor 28 Tahun 2018 about Copyright.

The formulation of the problem posed is: What is the legal protection of the copyright of Ceplok Segoro Amarto Batik motive in the city of Yogyakarta?

The results of this study indicate that the Ceplok Segoro Amarto motive batik has been protected by copyright, both obtained automatically because it has been manifested in a tangible form and the motive itself has been recorded in the Ministry of Law and Human Rights. The occurrence of copyright infringement can be submitted to the settlement efforts by resolving through alternative dispute resolution, submitting a claim for compensation to the Commercial Court or filing a criminal claim. This study recommends the need for the Dekranasda of Yogyakarta City and Yogyakarta City Government to make an announcement to the general public that the Ceplok Segoro Amarto batik motif is one of the typical batik of Yogyakarta City and is protected by copyright 
under Undang-Undang Nomor 28 Tahun 2018 about Copyright.

Key Words : Protection, Copyright, Ceplok Segoro Amarto

\section{PENDAHULUAN}

Hak cipta merupakan cabang Hak Kekayaan Intelektual (HKI) yang melindungi ciptaan manusia di bidang seni, sastra dan ilmu pengetahuan. Hak cipta adalah hak eksklusif pencipta yang timbul secara otomatis berdasarkan prinsip deklaratif setelah suatu ciptaan diwujudkan dalam bentuk nyata tanpa mengurangi pembatasan sesuai dengan ketentuan perundang - undangan ( Pasal 1 UU 28/14 tentang Hak Cipta). Pendaftaran bukanlah suatu keharusan karena tanpa didaftarkan hak cipta telah ada, diakui, dan dilindungi (Jened, 2014:104).

Batik merupakan salah satu karya ciptaan yang dilindungi oleh hak cipta. Hal tersebut diatur dalam Pasal 40 UU Hak Cipta. Jangka waktu perlindungan hak cipta atas karya seni batik kontemporer berlaku selama 70 (tujuh puluh) tahun. Karya seni batik yang dimaksud dalam UU Hak Cipta yaitu adalah motif batik kontemporer yang bersifat inovatif, masa kini, dan bukan tradisional. Karya tersebut dilindungi karena mempunyai nilai seni, baik dalam kaitannya dengan gambar, corak, maupun komposisi warna ( Pasal 40 UU 28/14 tentang Hak Cipta).
Batik dengan motif Ceplok Segoro Amarto diciptakan oleh Ignatius Suparjoko selaku pensiunan PNS Kota Yogyakarta. Ignatius Suparjoko berhasil menjuarai lomba desain motif batik khas Yogyakarta yang digelar oleh Dewan Kerajinan Nasional Daerah Kota Yogyakarta (Deskranada Kota Yogyakarta) dalam rangka HUT ke68 Pemkot Yogyakarta pada tahun 2015 silam. Meskipun sebagai pencipta batik motif Ceplok Segoro Amarto, Ignatius Suparjoko tidak keberatan hak cipta atas karyanya dipegang oleh Dekranasda Kota Yogyakarta, termasuk untuk dijadikan seragam PNS dalam lingkup Pemerintah Kota Yogyakarta

(https://daerah.sindonews.com).

Dekranasda Kota Yogyakarta sebagai pemegang hak cipta mengizinkan batik motif Ceplok Segoro Amarto untuk diproduksi untuk kepentingan ekonomi namun hanya boleh diproduksi oleh perajin di bawah binaan Dekranasda Kota Yogyakarta. Produksi batik motif Ceplok Segoro Amarto juga hanya boleh diproduksi dengan cara tulis, cap, atau kombinasi keduanya. Meskipun telah disepakati bahwa pembuatan batik motif Ceplok Segoro Amarto harus menggunakan metode tulis dan/atau cap, namun pada tahun 2018 ditemukan terdapat beberapa toko di 
Yogyakarta yang menawarkan batik motif Ceplok Segoro Amarto yang dibuat dengan cara printing dan ditawarkan dengan harga dibawah yang sudah disepakati, yaitu hanya sebesar Rp90.000/potong.

Dalam perspektif hak cipta, penggandaan batik motif Ceplok Segoro Amarto yang diproduksi secara printing dan bukan dengan cara cap, tulis, atau kombinasi keduanya untuk tujuan ekonomi tanpa adanya izin dari pemegang hak cipta yakni Dekranasda Kota Yogyakarta merupakan suatu pembajakan. Pembajakan adalah Penggandaan Ciptaan dan/atau produk Hak Terkait secara tidak sah dan pendistribusian barang hasil penggandaan dimaksud secara luas untuk memperoleh keuntungan ekonomi ( Pasal 1 (Angka 23) UU 28/14 tentang Hak Cipta).

Dengan terjadinya pembajakan dalam bentuk penggandaan dan pendistribusian ini, maka hal ini menunjukan bahwa hak cipta batik motif Ceplok Segoro Amarto di Kota Yogyakarta belum dilindungi secara hokum. Untuk dapat melihat secara objektif atas ketiadaan perlindungan ini dapat dilihat dari hasil penelitian ini.

\section{METODOLOGI PENELITIAN}

Metode yang digunakan dalam penulisan ini adalah metode penelitian hukum normatif. Penelitian normatif merupakan penelitian hukum yang dilakukan dengan cara meneliti bahan pustaka atau data sekunder. Pada penelitian hukum jenis normatif, seringkali hukum dikonsepkan sebagai apa yang tertulis dalam peraturan perundang-undangan (law in books) atau hukum yang dikonsepkan sebagai kaidah atau norma yang merupakan petokan berperilaku manusia yang dianggap pantas (Selvy,2009:56). Penelitian ini menggunakan metode studi kepustakaan yang meliputi peraturan perundang-undangan terkait pengaturan mengenai hak cipta, buku-buku, penelitian, jurnal, serta sumber tulisan lainnya yang berkaitan. Pengumpulan bahan hukum di atas dilakukan dengan cara studi dokumen, yaitu mengkaji, menelaah dan mempelajari bahan-bahan hukum yang ada kaitannya dengan penelitian ini.

\section{HASIL DAN PEMBAHASAN}

Batik merupakan salah satu seni adiluhung dan mempunyai filosofi yang tinggi serta berkaitan erat dengan tata kehidupan yang mencerminkan budaya bangsa Indonesia yang perlu digali, dipelihara, dilestarikan, dan dilindungi secara hukum dari berbagai persaingan tidak sehat di bidang Hak Kekayaan Intelektual dan perdagangan dalam negeri maupun internasional (Permenrin No.74/2007).

Indonesia mempunyai beragam motif batik yang berasal dari berbagai daerah di seluruh Indonesia. Setiap daerah mempunyai motif batik yang menjadi ciri khas dari suatu 
daerah, misalnya Daerah Istimewa Yogyakarta yang terdiri dari 4 (empat) kabupaten dan 1 (satu) kota pasti memiliki motif batik khas daerah dan termasuk dalam jenis karya seni batik dengan kontemporer.

Salah satu tujuan bahwa setiap kabupaten/kota di Daerah Istimewa Yogyakarta mempunyai motif batik yang khas dari daerahnya masing-masing adalah untuk meningkatkan pendapatan dan kesejahteraan perajin batik lokal di bawah UMKM di tiap-tiap masing daerah, selain tujuan dari melestarikan batik dan menunjukkan ciri khas daerahnya yang kemudian diaplikasikan lewat media kain batik. Masing-masing daerah yang mempunyai motif batik khas daerahnya dengan jenis batik kontemporer sudah mendaftarkan motif batiknya kepada Kementerian Hukum dan Hak Asasi Manusia dan merupakan salah satu ciptaan yang dilindungi oleh UU Hak Cipta karena motif batik tersebut merupakan karya hasil pemikiran yang telah dituangkan dalam bentuk yang dapat dihitung dalam bentuk materi, dan dapat diproduksi ulang (Margono, 2010:26).

Batik motif Ceplok Segoro Amarto merupakan salah satu objek hak kekayaan intelektual dalam ruang lingkup hak cipta karena motif tersebut tercipta dari hasil olah pikir manusia yang kemudian menghasilkan suatu produk (Damian, 2004:1). Batik dalam UU Hak Cipta disebut dengan karya seni batik. Seni adalah ekspresi artistik individu, kolektif, atau komunal, yang berbasis warisan budaya maupun berbasis kreativitas penciptaan baru, yang terwujud dalam berbagai bentuk kegiatan dan/atau medium (Pasal 1 UU No. 5/17 tentang Pemajuan Kebudayaan ). Seni merupakan salah satu dari 10 (sepuluh) objek pemajuan kebudayaan sebagaimana dinyatakan dalam UU No. 5/17 tentang Pemajuan Kebudayaan, sehingga terdapat kewajiban bahwa Negara memajukan kebudayaan nasional Indonesia di tengah peradaban dunia dengan menjamin kebebasan masyarakat dalam memelihara dan mengembangkan nilai-nilai budayanya (Pasal 32 Ayat (1) UUD 1945).

Banyaknya motif batik kontemporer dari berbagai daerah di Indonesia yang mempunyai nilai jual ekonomi baik dalam pasar domestik maupun internasional, membawa konsekuensi bahwa Negara harus hadir dalam melindungi karya-karya ciptaan warga negaranya, termasuk dalam hal ini adalah batik motif Ceplok Segoro Amarto. Beragamnya motif batik khas daerah yang dapat menjadi potensi ekonomi bagi suatu daerah, menjadi perhatian pemerintah untuk mendirikan suatu lembaga independen yang berfungsi sebagai wadah dalam melestarikan, mengembangkan dan melindungi warisan budaya bangsa. Berdasarkan hal tersebut, dibentuklah suatu lembaga yang bernama Dewan Kerajinan Nasional 
(Dekranas) yang ada ditingkat nasional serta Dewan Kerajinan Nasional Daerah (Dekranasda) yang berada ditingkat Provinsi dan Kabupaten/ Kota. Salah satu pokokpokok program kerja Dekranas adalah untuk memfasilitasi kepada pengrajin untuk perlindungan Hak Kekayaan Intelektual dalam ruang lingkup merek, desain, hak cipta dan indikasi geografis (https://dekranas.id ).

Dewan Kerajinan Dunia (World Craft Council/WCC) telah menobatkan kota Yogyakarta sebagai Kota Batik Dunia pada tanggal 18 Oktober 2014 di Kota Dongyang, Republik Rakyat Tiongkok (RRT). Hal ini kemudian melahirkan kewajiban nyata bagi masyarakat Yogyakarta untuk menjaga dan melestarikan batik. Sebagai bentuk pelestarian batik, maka kota Yogyakarta menetapkan batik khas kota Yogyakarta, yaitu batik motif Ceplok Segoro Amarto. Batik motif Ceplok Segoro Amarto merupakan motif hasil karya cipta yaitu Ignatius Suparjoko selaku pemenang Juara I Lomba Desain Batik Khas Yogyakarta dengan tema "Swarna Istimewa Yogyakarta" yang diadakan oleh Dekranasda Kota Yogyakarta dan bekerja sama dengan Dinas Koperasi, Usaha Kecil Menengah, Tenaga Kerja dan Transmigrasi Kota Yogyakarta pada tahun 2017 (Puspitasari, 2018, Desember 11).

Berdasarkan peraturan kesepakatan Lomba Desain Batik Khas Yogyakarta, dinyatakan dalam syarat umum lomba adalah bahwa hasil karya yang masuk menjadi milik Dekranasda Kota Yogyakarta, sehingga Dekranasda Kota Yogyakarta berhak untuk memakai hasil karya motif batik dalam lomba tersebut untuk dilakukan perbanyakan atau penggandaan (Puspitasari, 2018).

Batik motif Ceplok Segoro Amarto telah mendapatkan Hak Cipta dari Kementerian Hukum dan Hak Asasi Manusia dengan Nomor Pencatatan 090081 (Puspitasari, 2018). Dalam Surat Pencatatan Ciptaan yang dikeluarkan oleh Direktur Jenderal Kekayaan Intelektual, tercatat pencipta batik motif Ceplok Segoro Amarto yaitu Ignatius Suparjoko dan pemegang hak cipta tercatat atas nama Dekranasda Kota Yogyakarta. Pencatatan tersebut dilakukan oleh Dekranasda Kota Yogyakarta karena telah terjadi peralihan hak atas ciptaan batik motif Ceplok Segoro Amarto.

Dekranasda Kota Yogyakarta sebagai pemegang hak cipta membawa konsekuensi hukum bahwa Dekranasda Kota Yogyakarta dapat memanfaatkan karya ciptaannya untuk kepentingan ekonomi ( Pasal 8 UU 28/14 tentang Hak Cipta) yang dalam hal ini adalah melakukan perbanyakan atau penggandaan atas batik motif Ceplok Segoro Amarto. Penggandaan tersebut selain dapat dilakukan oleh Dekranasda Kota Yogyakarta juga dapat dilakukan oleh perajin batik di Kota Yogyakarta yang telah mendapatkan izin dari Dekranasda 
Kota Yogyakarta. Penggandaan tersebut hanya boleh dilakukan oleh perajin yang berada di wilayah Kota Yogyakarta dan tidak boleh dilakukan oleh perajin di kabupaten/kota lain karena tujuan dari Dekranasda Kota Yogyakarta menjadikan batik motif Ceplok Segoro Amarto sebagai sebuah komoditas perdagangan adalah untuk memberikan kesejahteraan dan kemandirian kepada perajin Kota Yogyakarta dengan tujuan melestarikan batik dan menambah pendapatan ekonomi bagi UMKM yang berada di bawah pelatihan Dekranasda Kota Yogyakarta. Selain itu, penggandaan batik motif Ceplok Segoro Amarto adalah untuk diperkenalkan kepada khalayak umum bahwa batik motif Ceplok Segoro Amarto adalah salah satu motif khas Kota Yogyakarta sebagai bentuk publikasi.

Salah satu fungsi pencatatan hak cipta atas batik motif Ceplok Segoro Amarto adalah sebagai bentuk perlindungan hukum atas karya tersebut, meskipun batik motif Ceplok Segoro Amarto telah mendapatkan hak cipta yang diperoleh secara otomatis ketika ide motif batik tersebut diwujudkan dalam bentuk nyata, yaitu dalam bentuk kain batik. Menurut pendapat Phillipus M. Hadjon bahwa perlindungan hukum bagi rakyat sebagai tindakan pemerintah yang bersifat preventif dan represif. Perlindungan hukum yang preventif bertujuan untuk mencegah terjadinya sengketa, yang mengarahkan tindakan pemerintah bersikap hati-hati dalam pengambilan keputusan berdasarkan diskresi (Hadjon,1987:29).

Menurut Sudikno Mertokusumo, hukum berfungsi sebagai perlindungan kepentingan manusia. Agar kepentingan manusia terlindungi, hukum harus dilaksanakan. Pelaksanaan hukum dapat berlangsung secara normal, damai, tetapi dapat terjadi juga karena pelanggaran hukum. Pelanggaran hukum terjadi ketika subjek hukum tertentu tidak menjalankan kewajiban yang seharusnya dijalankan atau karena melanggar hak-hak subjek hukum lain. Subjek hukum yang dilanggar hak-haknya harus mendapatkan perlindungan hukum (HR, 2006: 280).

Pasal 9 UU Hak Cipta menyebutkan bahwa pemegang hak cipta mempunyai hak ekonomi untuk melakukan:
a. Penerbitan Ciptaan;
b. Penggandaan Ciptaan Dalam Segala Bentuknya;
c. Penerjemahan Ciptaan;
d. Pengadaptasian, Pengaransemenan, Atau Pentransformasian Ciptaan;
e. Pendistribusian Ciptaan Atau Salinannya;
f. Pertunjukan Ciptaan;
g. Pengumuman Ciptaan;
h. Komunikasi Ciptaan; Dan
i. Penyewaan Ciptaan.
Segala bentuk perbuatan yang dapat dilakukan oleh pemegang hak cipta sebagaimana disebutkan di atas merupakan salah satu langkah-langkah hukum yang 
dapat dilakukan oleh pemegang hak cipta untuk melindungi karyanya. Dalam hal konteks perlindungan hukum terhadap batik motif Ceplok Segoro Amarto, langkah hukum yang dapat dilakukan oleh Dekranasda adalah melakukan perlindungan hukum secara preventif atas motif Ceplok Segoro Amarto. UU Hak Cipta menyebutkan bahwa terdapat dua macam perlindungan hukum, yaitu:

\section{Perlindungan \\ Hukum Secara Preventif}

a. Pencatatan atas Ciptaan

Pencatatan merupakan salah satu upaya perlindungan hukum secara preventif. Pencatatan hak cipta bukan sesuatu yang wajib untuk dilakukan oleh pencipta atau pemegang hak cipta, karena fungsi pencatatan hanyalah sebagai bentuk kepemilikan atas hak cipta apabila terjadi sengketa dalam bentuk bukti secara tertulis. Kerangka perlindungan hak cipta bersifat otomatis dan lembaga pendaftaran hak cipta sebagai bukti awal pemilikan hak cipta. Pencatatan ciptaan dan produk hak terkait bukan merupakan suatu keharusan bagi pencipta, pemegang hak cipta atau pemilik hak terkait. Pelindungan suatu ciptaan dimulai sejak ciptaan itu ada atau teruwujud dan bukan karena pencatatan. Hal ini berarti suatu ciptaan baik yang tercatat maupun tidak tercatat tetap dilindungi (Pasal 64 Ayat
(2) UU 28/14 tentang Hak Cipta).

Pencatatan batik motif Ceplok Segoro Amarto oleh Dekranasda Kota Yogyakarta merupakan bentuk perlindungan hukum terhadap motif batik tersebut secara preventif. Untuk dapat dilakukan pencatatan, suatu karya harus memenuhi syarat sebagai berikut:

1) Karya Orisinal

Menurut ketentuan Berne Convention, unsur keaslian (originality) merupakan hal yang esensial agar suatu karya dapat diberikan perlindungan hak cipta. Persyaratan keaslian merupakan akibat langsung dari persyaratan asal ciptaan (authorship). Hal mendasar pada hak cipta adalah keaslian yang menyiratkan bahwa pemegang hak cipta atau pihak yang mengklaim sebagai pihak yang membuat karya tersebut (Jened, 2014:80).

Keaslian bukan menyiratkan kebaruan, melainkan hal tersebut menyiratkan bahwa yang bersangkutan tidak meniru karya orang lain. Keaslian atau orisinalitas adalah bahwa perwujudan gagasan atau ide itu benarbenar dari diri dan pikiran pencipta sendiri (Jened, 2014:81).

Pencipta adalah seorang atau beberapa orang yang secara 
sendiri-sendiri atau bersamasama menghasilkan suatu ciptaan yang bersifat khas dan pribadi ( Pasal 1 Angka (2) UU 28/14 tentang Hak Cipta). Berdasarkan penjelasan tersebut, dinyatakan bahwa suatu ciptaan harus bersifat khas dan pribadi. Batik motif Ceplok Segoro Amarto yang diciptakan oleh Ignatius Suparjoko merupakan karya orisinal dan bersifat khas, karena motif tersebut lahir dari ide-ide atau gagasan Ignatius Suparjoko dan motif serta polanya tidak memiliki persamaan dengan motif batik kontemporer lain. Meskipun pada lomba tersebut ketentuannya didasarkan pada diharuskannya pencantuman motif batik tradisional seperti Lor Semen, Ceplok (Kawung) dan Parang, akan tetapi terdapat pengekspresian ide motif batik sehingga pada tatanan motif, pola, warna dan filosofi berbeda dengan karya dari orang lain yang masuk dalam Lomba Desain Batik Khas Yogyakarta.

2) Diwujudkan dalam Bentuk Nyata

Persyaratan perwujudan (fixation) merupakan konsep bentuk material (material form) yang merujuk pada "suatu ciptaan" sebagai tujuan perlindungan hak cipta. Hak cipta melindungi ekspresi dalam bentuk material, bukan ide atau informasinya. Konsep bentuk material (material form) adalah konsep yang merujuk "suatu karya" sebagai tujuan perlindungan hak cipta. Belajar dari Eropa menginformasikan bahwa kata "karya" adalah suatu karya sastra, karya drama, karya musik, atau karya seni. Suatu ide menjadi karya manakala ide tersebut paling tidak harus dibuat dalam bentuk tertulis atau bentuk material lainnya (Jened,2014:84).

Ciptaan adalah setiap hasil karya cipta di bidang ilmu pengetahuan, seni, dan sastra yang dihasilkan atas inspirasi, kemampuan, pikiran, imajinasi, kecekatan, keterampilan, atau keahlian yang diekspresikan dalam bentuk nyata (Pasal 1 Angka (3) UU 28/14 tentang Hak Cipta). Frasa dalam bentuk nyata di dalam kalimat tersebut merupakan suatu persyaratan bahwa ciptaan dapat dilindungi oleh hak cipta ketika ide atau gagasan sudah diwujudkan dalam bentuk yang nyata. Hal ini merupakan syarat penting ketik akan dilakukan pencatatan suatu ciptaan, karena permohonan pencatatan ciptaan haruslah menyertakan contoh ciptaan (Pasal 66 Ayat (2) UU 28/14 tentang Hak Cipta). Suatu ide tidak dapat dicatatkan ketika belum diwujudkan dalam bentuk yang nyata, karena ide tersebut hanya berada pada pikiran si pencipta dan orang lain tidak dapat melihat dengan panca indera, sehingga ketika 
terjadi sengketa akan sulit dibuktikan kebenarannya ketika hanya masih menjadi ide.

Batik motif Ceplok Segoro Amarto telah diwujudkan dalam wujud yang nyata, yaitu dibuat dalam bentuk kain batik. Perwujudan ciptaan dalam bentuk kain batik tersebut selain berfungsi sebagai syarat ciptaan untuk dapat dilindungi hak cipta, kain batik tersebut juga sebagai contoh pengerjaan Batik Ceplok Segoro Amarto oleh pengrajin batik di Kota Yogyakarta untuk dapar meningkatkan pendapatan ekonomi mereka. Pengrajin yang dapat memproduksi Batik Ceplok Segoro Amarto hanyalah pengrajin di Kota Yogyakarta dan telah mendapatkan izin dari Dekranasda Kota Yogyakarta untuk melakukan penggandaan atas batik motif Ceplok Segoro Amarto.

Batik motif Ceplok Segoro Amarto dapat dikatakan telah mendapatkan perlindungan hukum dalam bidang hak cipta, sesuai dengan ketentuan UU Hak Cipta. Meskipun batik motif Ceplok Segoro Amarto telah mendapatkan hak cipta yang diperoleh secara otomatis, akan tetapi Dekranasda Kota Yogyakarta selaku pemegang hak cipta merasa perlu untuk mencatatkan batik motif Ceplok Segoro Amarto agar mendapatkan perlindungan hukum secara preventif sebagai bentuk bukti kepemilikan secara tertulis untuk mencegah terjadinya pelanggaran hak cipta di kemudian hari.

Dapat dipahami bahwa fungsi pencatatan hak cipta dimaksudkan untuk memudahkan pembuktian dalam hal terjadi sengketa mengenai hak cipta. Pencatatan ini tidak mutlak diharuskan, karena tanpa pencatatan hak cipta sudah dilindungi. Hanya mengenai ciptaan yang tidak dicatatkan akan lebih sukar dan lebih memakan waktu dalam pembuktiannya. Dari penjelasan umum tersebut dapatlah disimpulkan bahwa pencatatan itu bukanlah syarat untuk sahnya (diakui) suatu hak cipta, melainkan hanya untuk memudahkan suatu pembuktian bila terjadi sengketa. Hal yang penting lagi dari pencatatan ini adalah dengan pencatatan diharapkan dapat memberikan semacam kepastian hukum serta lebih memudahkan dalam prosedur pengalihan haknya (Saidin,2015:248)

b. Produksi dan Dokumentasi Batik Motif Ceplok Segoro Amarto

Produksi kain batik dengan motif Ceplok Segoro Amarto merupakan salah satu langkah hukum yang dilakukan oleh Dekranasda Kota Yogyakarta 
sebagai bentuk publikasi kepada khalayak umum bahwa batik motif Ceplok Segoro Amarto merupakan batik khas Kota Yogyakarta. Produksi batik tersebut juga merupakan hak ekonomi dari Dekranasda Kota Yogyakarta selaku pemegang hak cipta untuk memanfaatkan motif Ceplok Segoro Amarto yang digunakan untuk mendapatkan keuntungan ekonomi dari motif tersebut sebagaimana disebutkan dalam Pasal 9 UU Hak Cipta bahwa pemegang hak cipta berhak untuk melakukan penggandaan dan pendistribusian atas ciptaannya.

Dokumentasi merupakan langkah hukum yang bertujuan untuk menyediakan bukti bahwa batik motif Ceplok Segoro Amarto adalah karya ciptaan milik Dekranasda Kota Yogyakarta apabila terjadi sengketa pelanggaran hak cipta. Dokumentasi dapat berupa pengumpulan dokumendokumen terkait dengan pencatatan hak cipta, pengumpulan dokumen proses produksi batik motif Ceplok Segoro Amarto misalnya berupa foto dan contoh kain batik motif Ceplok Segoro Amarto, serta pengumpulan desain motif Ceplok Segoro Amarto yang dibuat oleh pencipta yang belum diwujudkan secara nyata dalam bentuk kain batik atau masih berupa desain di atas kertas atau media lain.

c. Pemberian Label pada Batik

Label merupakan suatu bagian dari sebuah produk yang membawa informasi verbal tentang produk atau penjualnya

(Angipora,202:192). Pemberian label pada kain batik merupakan hal yang penting sebagai salah satu fungsi publikasi yang menyatakan bahwa kain batik motif Ceplok Segoro Amarto merupakan batik khas Kota Yogyakarta. Informasi yang dimuat dalam label tersebut adalah filosofi motif batik, tata cara perawatan batik dan logo Dekranasda Kota Yogyakarta yang secara tersirat menerangkan bahwa Dekranasda Kota Yogyakarta selaku pemegang hak cipta batik motif Ceplok Segoro Amarto yang berhak untuk melakukan perbanyakan atau penggandaan kain batik motif Ceplok Segoro Amarto sesuai hak ekonomi yang melekat daripadanya.

Meskipun label tersebut telah memuat logo Dekranasda Kota Yogyakarta, akan tetapi tidak ada informasi yang menyebutkan bahwa batik motif Ceplok Segoro Amarto telah dilindungi oleh hak cipta berdasarkan mekanisme pencatatan hak cipta kepada Kementerian Hukum dan Hak 
Asasi Manusia. Berdasarkan hal tersebut, pencantuman nomor pencatatan yang terdapat dalam Surat Pencatatan Ciptaan diperlukan agar masyarakat mengetahui bahwa batik motif Ceplok Segoro Amarto telah dilindungi oleh hak cipta berdasarkan mekanisme pencatatan sehingga mencegah terjadinya pelanggaran hak dari Dekranasda Kota Yogyakarta selaku pemegang hak cipta berupa penggandaan atau pembajakan ciptaan ataupun pelanggaran lain misalnya diakui kepemilikannya batik motif Ceplok Segoro Amarto oleh pihak lain.

\section{Perlindungan \\ Secara Represif}

Hukum

Perlindungan hukum represif adalah suatu bentuk perlindungan hukum di mana lebih ditujukan dalam penyelesian sengketa (Mertokusumo,2009:38).Perlindu ngan hukum represif merupakan perlindungan akhir berupa sanksi seperti denda, penjara, dan hukuman tambahan yang diberikan apabila sudah terjadi sengketa atau telah dilakukan suatu pelanggaran (Muchsin, 2003:14).Sehubungan dengan telah dicatatkannya batik motif Ceplok Segoro Amarto kepada Kementerian Hukum dan Hak Asasi Manusia dan telah mendapatkan Surat Pencatatan Ciptaan, maka batik motif Ceplok Segoro Amarto telah mendapatkan perlindungan hukum akan hak cipta karya seni batik sebagaimana yang telah diatur dalam UU Hak Cipta. Namun, meskipun telah mendapatkan perlindungan hukum terhadap hak cipta batik motif Ceplok Segoro Amarto yang mana secara tersurat pihak lain tidak boleh memanfaatkan batik motif Ceplok Segoro Amarto untuk meraup keuntungan ekonomi, akan tetapi pada kenyataannya terdapat dua kasus pelanggaran hak cipta atas motif batik tersebut.

UU Hak Cipta mengatur bahwa terdapat 3 (tiga) cara penyelesaian sengketa hak cipta, di antaranya yaitu:

a. Penyelesaian Sengketa Secara Perdata

Sengketa terhadap hak cipta merupakan sengketa terhadap harta kekayaan yang dalam terminologi hak cipta disebut sebagai economic rights atau hak ekonomi. Sengketa-sengketa itu tidak hanya berpangkal pada adanya perbuatan melawan hukum yang menyebabkan menimbulkan kerugian kepada pencipta ataupun pemegang hak cipta yang dilakukan oleh pihak lain (Saidin,2015:265).

Pencipta atau pemegang hak cipta memiliki hak ekonomi untuk melakukan (Pasal 9 (Ayat 1) UU 28/14 Ttg Hak Cipta):

a. penerbitan ciptaan;

b. penggandaan ciptaan dalam segala bentuknya;

c. penerjemahan ciptaan;

d. pengadaptasian, pengaransemenan, pentransformasian ciptaan; 
e. pendistribusian ciptaan atau salinannya;

f. pertunjukan ciptaan;

g. pengumuman ciptaan;

h. komunikasi ciptaan; dan

i. penyewaan ciptaan.

Sehubungan dengan Pasal di atas, disebutkan bahwa pencipta atau pemegang hak cipta memiliki hak ekonomi untuk melakukan 9 (Sembilan) kegiatan di atas, termasuk melakukan penggandaan ciptaan dalam segala bentuknya. Segala kegiatan di atas hanya dapat dilakukan oleh pencipta atau pemegang hak cipta sesuai dengan yang tertera dalam Surat Pencatatan Ciptaan atau atau oleh pihak lain yang telah mengantongi izin dari pencipta atau pemegang hak cipta berdasarkan perjanjian.

Meskipun batik motif Ceplok Segoro Amarto telah mendapatkan perlindungan hukum secara preventif dengan cara melakukan pencatatan atas batik motif Ceplok Segoro Amarto, namun pelanggaran hak cipta masih saja terjadi. Terdapat 2 (dua) kasus pelanggaran hak cipta akan batik motif Ceplok Segoro Amarto.

Pertama, kasus pembajakan batik motif Ceplok Segoro Amarto yang diproduksi secara printing oleh pengrajin di Kota Yogyakarta. Dekranasda Kota Yogyakarta selaku pemegang hak cipta batik motif Ceplok Segoro Amarto menyatakan bahwa pembuatan batik dengan motif tersebut harus dilakukan secara tulis, cap atau kombinasi keduanya. Kedua, kasus pembajakan batik motif Ceplok Segoro Amarto oleh pengusaha batik di Kabupaten Bantul dengan tidak meminta izin kepada Dekranasda Kota Yogyakarta, sekalipun batik tersebut diproduksi secara kombinasi antara tulis dan cap. Pembuatan batik dengan motif Ceplok Segoro Amarto hanya boleh dilakukan oleh pengrajin yang berdomisili di Kota Yogyakarta dan telah meminta izin kepada Dekranasda Kota Yogyakarta atau pengrajin UMKM yang berada di bawah naungan Dekranasda Kota Yogyakarta, artinya tidak boleh diproduksi oleh pengrajin di luar daerah Kota Yogyakarta. Salah satu alasan pembuatan batik dengan motif Ceplok Segoro Amarto hanya boleh dilakukan oleh pengrajin di Kota Yogyakarta adalah untuk meningkatkan kesejahteraan dan pendapatan ekonomi pengrajin atas permintaan pasar terhadap batik dengan motif tersebut ( Putra A.P ( 2018, November 30 )).

Kedua kasus di atas termasuk dalam pelanggaran hak cipta berupa pembajakan. Penggandaan Ciptaan dan/atau produk Hak Terkait secara tidak sah dan pendistribusian barang hasil penggandaan dimaksud secara luas untuk memperoleh keuntungan ekonomi (Pasal 1 (Angka 23) UU 28/14 Ttg Hak Cipta). Penyelesaian sengketa hak cipta dapat ditempuh dengan cara melakukan gugatan ganti rugi secara perdata, tuntutan secara pidana maupun diselesaikan melalui penyelesaian sengketa alternative (Pasal 95 (Ayat 1) UU 28/14 Ttg Hak Cipta). 
Melalui mekanisme penyelesaian sengketa secara perdata, baik pencipta maupun pemegang hak cipta dapat meminta ganti rugi.

\section{b. Penyelesaian Sengketa Secara Pidana}

Sanksi pidana ditujukan untuk menghukum setiap orang yang secara sengaja melakukan tindakan pembajakan, sama seperti dalam kasus perdata tujuannya untuk mencegah pelanggaran lebih lanjut. Tujuan dari penghukuman disediakan adalah denda dan/ atau penjara secara konsisten dengan hukuman yang diberlakukan pada tindak pidana yang serius. Dalam hal ini merujuk pada ketentuan Article 61 TRIPs yang menentukan (Jened,2014:230) :

"Member shall provide for criminal procedures and penalities to be applied at least in cases of wilful trademark counterfeiting or copyright piracy on commercial scale..."

Dalam kasus pembajakan batik motif Ceplok Segoro Amarto, pembajakan adalah hal yang dilarang oleh UU Hak Cipta. Bagi pelaku pembajakan, pihak yang dirugikan yang dalam hal ini adalah pencipta atau pemegang hak cipta sesuai ketentuan perundangundangan dapat mengajukan tuntutan secara pidana. Pelaku pembajakan dapat dikenai sanksi pidana berupa denda dan/ atau penjara. Tuntutan pelanggaran hak cipta secara pidana merupakan bentuk delik aduan ( Pasal $120 \mathrm{UU}$
28/14 Ttg Hak Cipta). Delik aduan adalah delik yang hanya dapat dituntut karena adanya pengaduan dari pihak yang dirugikan (Lamintang,1990:154). Artinya, tuntutan pidana hanya dapat diajukan oleh pencipta atau pemegang hak cipta yang hak moral dan/ atau hak ekonominya dilanggar oleh pihak lain.

Tuntutan secara pidana dalam kasus pelanggaran hak cipta juga dapat disertai dengan tuntutan ganti rugi oleh pencipta atau pemegang hak cipta. Permohonan ganti rugi dapat dilakukan oleh subjek hukum yang haknya dilanggar oleh pihak lain, yang mana dapat dicantumkan dalam amar putusan pengadilan perkara tindak pidana hak cipta ( Pasal 96 (Ayat 2) UU 28/14 Ttg Hak Cipta). Jika pencipta atau pemegang hak cipta tidak melayangkan tuntutan akan pelanggaran hak cipta karya ciptaannya, maka proses peradilan tidak akan berjalan sebagaimana mestinya.

\section{1) Alternatif Penyelesaian Sengketa}

UU Hak Cipta menyatakan bahwa sengketa pelanggaran hak cipta sebelum diselesaikan melalui pengadilan dalam bentuk tuntutan pidana atau gugatan perdata, para pihak harus terlebih dahulu menempuh upaya alternatif penyelesaian sengketa. Penyelesaian sengketa melalui nonlitigasi jauh lebih efektif dan efisien sebabnya pada masa belakangan ini, berkembangnya berbagai cara penyelesaian sengketa (settlement 
method) di luar pengadilan, yang dikenal dengan ADR dalam berbagai bentuk, seperti (http://repository.unpas.ac.id) :

\section{1) Arbitrase}

Pasal 1 ayat (1) Undang-Undang No 30 Tahun 1999 menjelaskan bahwa, "Arbitrase adalah cara penyelesaian suatu sengketa perdata di luar pengadilan umum yang didasarkan pada perjanjian arbitrase yang dibuat secara tertulis oleh para pihak yang bersengketa".

Arbitrase digunakan untuk mengantisipasi perselisihan mungkin terjadi maupun yang sedang mengalami perselisihan yang tidak dapat diselesaikan secara negosiasi/konsultasi maupun melalui pihak ketiga serta untuk menghindari penyelesaian sengketa melalui peradilan.

\section{2) Negosiasi}

Menurut Ficher dan Ury, negosiasi merupakan komunikasi dua arah yang dirancang untuk mencapai kesepakatan pada saat kedua belah pihak memiliki berbagai kepentingan yang sama maupun yang berbeda.

Hal ini selaras dengan apa yang diungkapkan oleh Susanti Adi Nugroho bahwa, negosiasi ialah proses tawar-menawar untuk mencapai kesepakatan dengan pihak lain melalui proses interaksi, komunikasi yang dinamis dengan tujuan untuk mendapatkan penyelesaian atau jalan keluar dari permasalahan yang sedang dihadapi oleh kedua belah pihak.

3). Mediasi

Menurut Peraturan Mahkamah Agung No 1 Tahun 2016 Tentang Prosedur Mediasi di Pengadilan adalah cara penyelesaian sengketa melalui proses perundingan untuk memperoleh kesepakatan para pihak dengan dibantu mediator.

Mediasi (mediation) melalui sistem kompromi (compromise) diantara para pihak, sedang pihak ketiga yang bertindak sebagai mediator hanya sebagai penolong (helper) dan fasilitator.

3) Konsiliasi

Konsiliasi merupakan lanjutan dari mediasi. Mediator berubah fungsi menjadi konsiliator. Dalam hal ini konsiliator menjalankan fungsi yang lebih aktif dalam mencari bentuk-bentuk penyelesaian sengketa dan menawarkannya kepada para pihak. Jika para pihak dapat menyetujui, solusi yang dibuat konsiliator akan menjadi resolution.

4) Penilaian Ahli

Penilaian ahli merupakan cara penyelesaian sengketa oleh para pihak dengan meminta pendapat atau penilaian ahli terhadap perselisihan yang sedang terjadi.

\section{KESIMPULAN}

Berdasarkan penjelasan yang telah dijelaskan di atas, batik motif Ceplok Segoro Amarto belum 
mendapatkan perlindungan hukum secara optimal. Secara preventif artinya batik motif Ceplok Segoro Amarto berdasarkan UU Hak Cipta telah mendapatkan perlindungan hukum karena sudah mencatatkan ciptaannya yang dilakukan oleh Dekranasda Kota Yogyakarta selaku pemegang hak cipta serta melakukan publikasi dengan cara melakukan produksi batik dan dokumentasi proses pembuatan batik serta memberikan informasi bahwa batik motif Ceplok Segoro Amarto label produksi batik motif Ceplok Segoro Amarto. Pencatatan ciptaan bukanlah sebuah keharusan bagi pemegang hak cipta, karena hak cipta didapatkan secara otomatis berdasarkan prinsip deklaratif ketika suatu ide yang orisinal diwujudkan dalam suatu bentuk yang nyata. Namun demikian, perlindungan hukum secara represif berarti bahwa Dekranasda Kota Yogyakarta selaku pemegang hak cipta mempunyai hak untuk melakukan langkah hukum apabila terjadi sengketa pelanggaran hak cipta yang dilakukan oleh pihak lain secara melawan hukum. Dalam kasus batik Ceplok Segoro Amarto hal tersebut belum dilakukan penegakan hak cipta.

\section{DAFTAR PUSTAKA}

Angipora, Marinus. (2002). DasarDasar Pemasaran. Jakarta: PT Raja Grafindo Persada.

Damian, Eddy. (2014) .Hukum Hak Cipta. Bandung: PT Alumni.
Hadjon, Philipus M. (1987) Perlindungan Hukum Bagi Rakyat Indonesia. Surabaya : Bina Ilmu.

HR, Ridwan. (2006) Hukum Administrasi Negara. Jakarta: Raja Grafindo Persada.

https://daerah.sindonews.com/re ad/1010429/151/pertama-

berlomba-pensiunan-pns-juara-i1433818969, diakses pada tanggal 26 Oktober 2018 pukul 00.41 WIB.

https://dekranas.id/wpcontent/uploads/2016/12/11.BUKU_AD-ART-FINAL.per-6Okt_TRB_19_11_2015-CopyPRINT_HUMAS.pdf, diakses pada tanggal 14 Desember 2018 pada pukul 17.58 WIB.

http://repository.unpas.ac.id/286 32/4/G.\%20BAB\%20II.pdf, diakses pada tanggal 26 Desember 2018 pukul 00.47 WIB.

Jened, Rahmi. (2014) Hukum Hak Cipta. Bandung: PT Citra Aditya Bakti.

Lamintang, P.A.F. (1990). DasarDasar Hukum Pidana Indonesia. Bandung: Sinar Baru

Margono, Suyud. (2010). Hukum Hak Cipta Indonesia. Bogor: Ghalia Indonesia.

Mertokusumo, Sudikno. (2010). Penemuan Hukum. Bandung: Citra Aditya Bakti. 
Muchsin. (2003). Perlindungan dan Kepastian Hukum bagi Investor di Indonesia. Surakarta: Universitas Sebelas Maret.

Saidin, OK. (2016). Aspek Hukum Hak Kekayaan Intelektual (Intellectual Property Rights). Depok: Rajawali Press.

Selvy. (2009). Keterbukaan Informasi Pelaksanaan Penawaran Umum Oleh Calon Emiten di tengah Masalah Penghentian Kegiatan Usaha Anak Perusahaan: Studi Kasus Penawaran Umum PT. Bayan Resources, Tbk. Skripsi. Jakarta: Universitas Indonesia. 